\title{
تقويم كتاب الاحياء للصف الرابع العلمي من وجهة نظر المدرسين والمدرسات
}

م · م م مجدان نادر عودة الركابي

م · م م • مصطفى زهير

\section{ملخص البحث}

يهدف البحث الحالي الى تقويم كتاب الاحياء للصف الرابع العام من وجهة نظر المدرسين

$$
\text { والمدرسات وتحدد البحث الحالي بـ }
$$

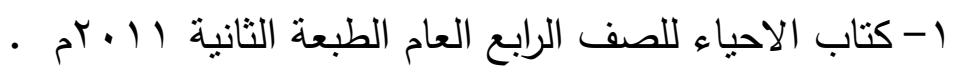

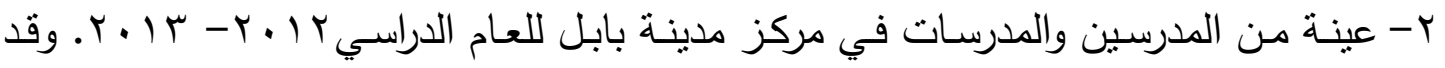

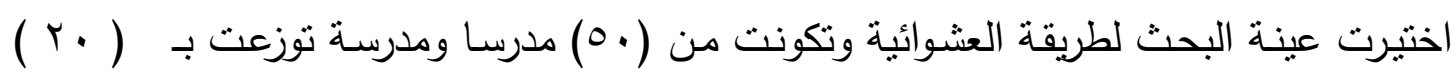

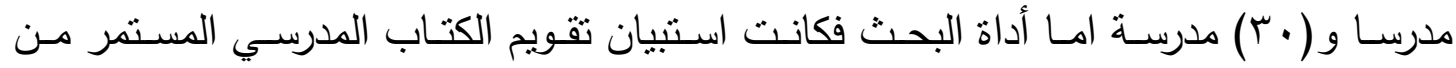
الدراسات السابقة في هذا المجال تكونت الاداة من ( ع 7) فقرة هي مقدمة الكتاب بواقع ( (0) فقرات اهداف الكتاب بواقع ( T ) فقرة موضوعات الكتاب بواقع ( Tا فقرة ) الاسئلة والنشاط في نهايـة كل فصل من فصول الكتاب بواقع ( V فقرة ) الصور والرسوم التوضيحية بواقع (

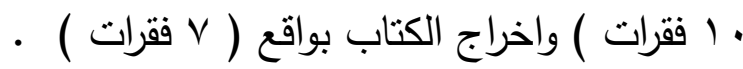
عرضت الاستبيان على مجموعه من الخبراء في علم النفس وطرائق التدريس والعلوم وقد حصلت على نسبة اتفاق ( 0^\% ) وهي تعد مقبولة أي حصلت على الصدق الظاهري ـ ثم عرضـها

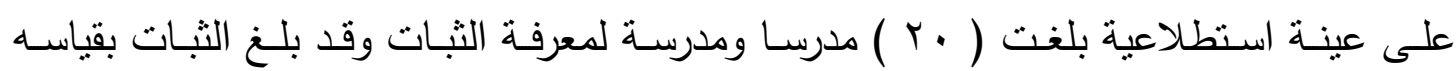
بمعامل الارتباط بيرسون ( \% \% ) وهنا اصبح الاستبيان جاهزا لعرضـة على عينة البحث الرئيسية ـ استخدم الباحث الوسـائل الاحصـائية وهي معامل ارتباط بيرسون • والوسط المرجح لاستخراج حدة الفقرة والوزن المئوي والانحراف المعياري بوصفها وسائل احصائية لتحليل البيانات وبينت النتائج ان الكتاب جيد بصورة عامة ويصلح ليكون منهجا للأحياء للصف الرابع العلمي ولكن الكتاب لا يشجع على التفكير الناقد والتفكير الإبداعي وان الرسومات والصور لا تستطيع اثارة الطلبة وان اسئلة نهاية الفصل في الكتاب والنشاط لا تمكن الطالب من ابداء رأيه ولا تراعي الجانب المهاري ولا الوجداني وان موضوع الانسجة النباتية هو موضوع صعب من وجهة نظر 


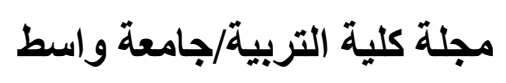

\begin{abstract}
The current research aims at evaluating the biology book for fourth grade year, from the standpoint of teachers and identifies current research $b$.
\end{abstract}

1 - Biology Book for Fourth Scientific Grade, second edition Y.11 $r$ - A sample of teachers of both gender at the center of the city of Babylon for the academic year $r_{-}, r_{-} r_{-} \mid r$. It was selected sample randomly which consisted of $\left(\mathcal{O}^{\cdot}\right)$, a teacher and a school divided by $(r \cdot)$ male teachers and $(r \cdot)$ female teachers either search tool was a questionnaire for the textbook continuing studies previous work in this area consisted tool ( $7 \leqslant$ ) paragraph is introduction by $(0)$ paragraphs of book in amount ( 1 r), paragraph subjects of the book by (I r paragraphs) Questions and activity at the end of each chapter of the book by ( IV paragraphs ) pictures and illustrations by $(1 \cdot$ paragraphs) editing the book by ( $\vee$ paragraphs) The questionnaire presented to a group of experts in psychology and teaching methods of science, it has got a percentage of agreement $(\wedge 0 \%)$ which is no longer acceptable got a virtual honesty. Then displayed on the sample to an exploratory amounted $(r \cdot)$ female and male teachers to see stability, it has reached the consistency measured by correlation coefficient Pearson ( $10 \%$ ), and here the questionnaire became ready for submission to the major search sample .

The researcher used statistical methods, a Pearson correlation coefficient . the weighted average extraction unit paragraph and weight percentile and standard deviation as a means of statistical data analysis and the results show that the book is good in general, and is fit to be a method for Biology to fourth scientific grade , but the book does not encourage critical and creative thinking, graphics and images can not provoke the students and the ratchet end of the chapter in the book and the activity does not enable the student to express his opinion and do not take into account the skill nor the emotional side and the subject of plant tissue is a difficult subject from the viewpoint of teachers. 


\section{(الفصل الأول}

الهمية البحث ومشكتثه :

تعد التربية وسيلة المجتمع لتربيـة أبنائه وفقا للاتجـاه الذي يرغبـه ذلك المجتمع اذ يعد المنهج الاداة الفاعلة بيد الطالب والمدرس ليمثل محتواه المادة التربوية التي تجسد رغبة واتجاه المجتمعات في بناء الأجيال . المباء المنـاهج هي الوسيلة المحكمة التي تهيمن بها السياسـات التعليمية على العقول وبناء الفكر (الهاثـمي، 999 (، صوهب ()). لان التربية مطلوب منها احداث التأثيرات والتغيرات في حياة المجتمعات لكي تنير تلك المجتمعات نحو التقدم والازدهار . وتعد المناهج وسيلة التربية لتحقيق اهدافها المخطط لها، وذلك بما تقدمه المناهج للمتعلم من خبرات متعددة تساعده على

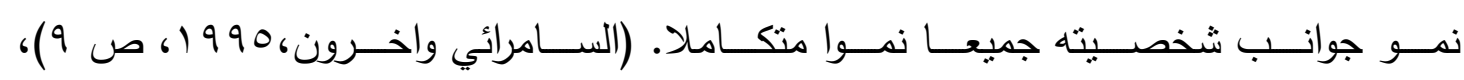

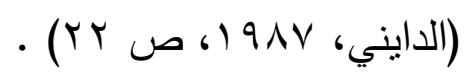

وقد مرت المناهج بتطورات مهمة وانتقلت من المفهوم القديم للمنهج الذي كان يؤكد على المقررات الدراسية التي تتيحهـا المدرسـة لطلبتهـا داخل جدرانها بغيـة تقيمهم في نهايـة العـام الدراسسي حيث تحولت المناهج بفضل التطورات الحاصلة في العلم وفي العلوم الصـرفة بحيث اصبحت نتمل معنى اوسع واشتل من ذللك. فالمنهج هو الخبرات التربوبة كلها التي خططت لها هيئات تربوية مختصـة ونظمت في سلسلة متدرجة تراعي امكانات التعليم والتعلم والمدة الزمنية المحددة بهدف مساعدة كل متعلم على النمو الثـامل وفقا لأهداف مرسومة واستراتيجيات محددة ترتبط ارتباطسا وثيقا بأهداف المجتمـع واسـتراتيجياته التي تقدم للمتعلمين تحت اشتراف المدرسـة

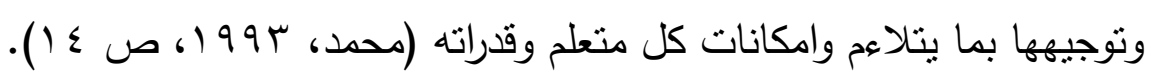
فالمنهج ينصب على ترجمة الاهداف التربوية إلى مواقف وخبرات يتفاعل معها الطلبة ليتعلموها ويساعد على رفع كفاءة المربين وفاعليتهم من خـل فهم القوى المختلفة المؤثرة في صياغة المنهج وبنائه، ومعرفة الاهداف وكيفية اشتقاقها من مصادرها، والوقوف على الاسس والمعايير المستخدمة في اختيار الخبرات والمحتوى الذي يقدم للطلبة في أي مستوى دراسي وفي تحديد طرائق التدريس المناسبة (محمد، (99 (1، صع ( ). 
ونظرا لأهمية المناهج في العملية التربوية ودور تلك المناهج في بناء الاجيال وترسيخ القيم التي ترغبها المجمعات لأجيالها فان التربية بدأت في المراحل الاخيرة نركز على الاهتمام بالمنهج المدرسي بما يعزز مكانته ودوره. ونظرا لما تمليه الفلسفات النقدمية من مفاهيم تخص ودره، المنهج وتطوره فقد اكدت الاتجاهات

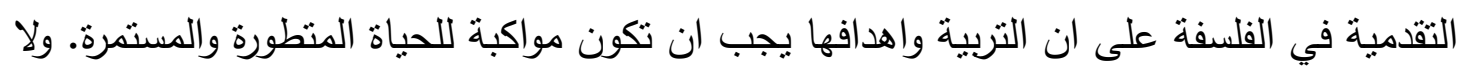
يوجد منهج ثابت جامد على الدوام يستجيب للتغيرات من غير ان تحدث له مراجعة وتطوير ولابد

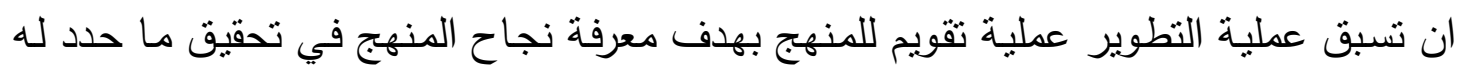

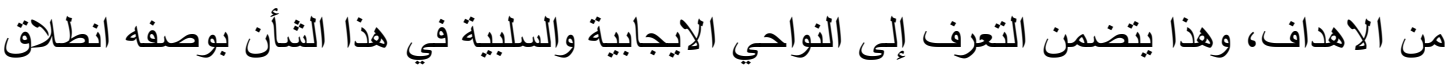

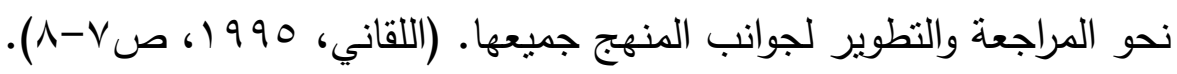

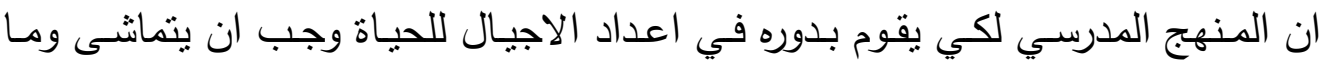
يحصل فيها من متغيرات علمية وتقنية، وان يساعدهم على التكيف معها، وان يكون مرنا قابلا

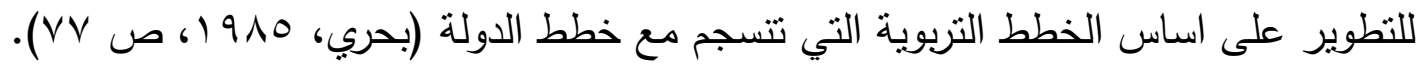
وقد اكد محمد 1991 ان الفلسفات ذات الاتجاه التقدمي ترى ان اهداف التربية متغيرة

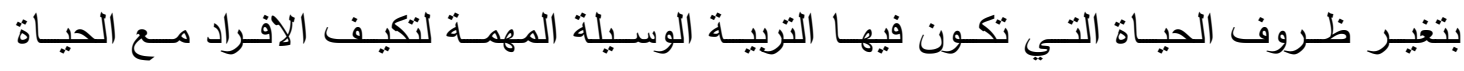

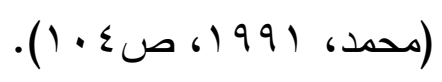

والكتاب المدرسي ترجمة للمنهج وتطبيق للأسـاليب التزبويـة الحديثة، فطبيعة محتواه وخصائص بنيته المعرفية تمثل المستويات والاهداف والمفاهيم التي تعد سليمة من الناحيتين

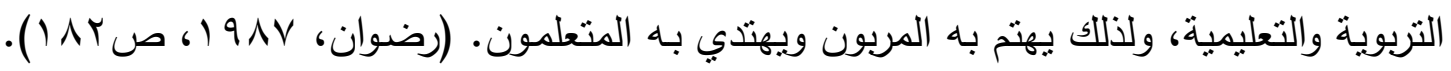

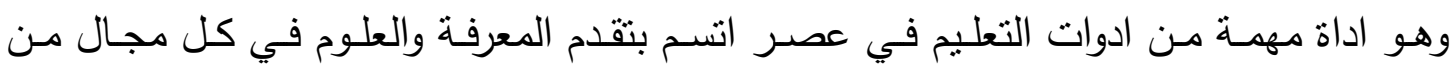

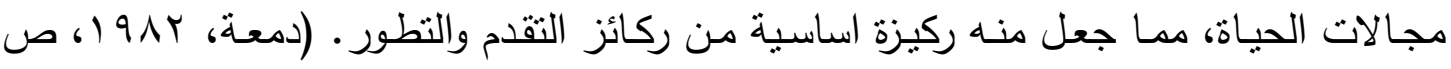
. ( $\ \vee-7 \varepsilon$

وانطلاقا من اهيبة التربية ودورها في الحياة المعاصرة ونظرا لأهمية المنهج والكتاب ودورهما في العملية التربوية فان اهمية عملية التقويم تتبثق من اهمية التربية والمنهج والكتاب.

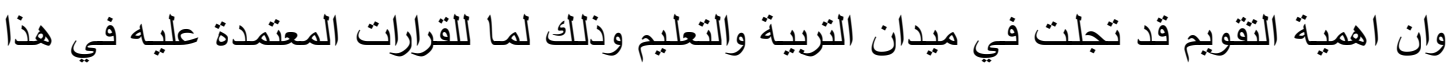
الميدان من اثار عظيمة تنعكس على الاجيال ثم على المجتمع كله ولاسيما ان التربية في هذا

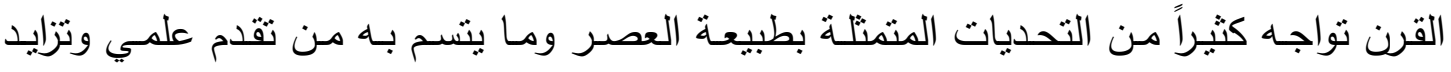
سكاني وانفتاح عـالمي مما يفرض المراجعـة والتعديل الدائمين في عناصر العملية التعليمية

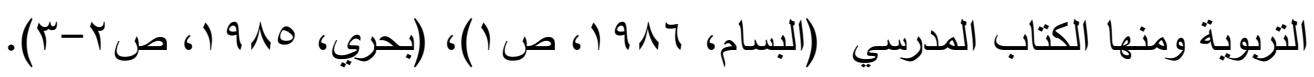




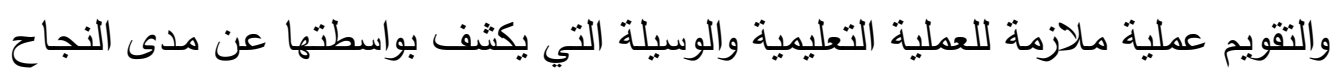

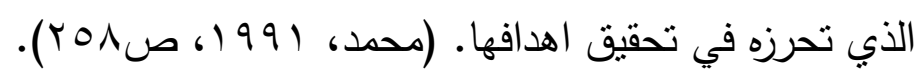

لذا توجب ان نجري عمليات فحص هذا الواقع للكتب المدرسية وتنيان ما فيه من جوانب ايجابية وسلبية وصولاً إلى تطويره ليصبح بإمكانه مواكبة التطور الحاصل في الحياة وتأدية لئل الدور المطلوب من المنهج والكتاب كما يجب.

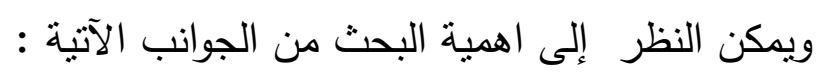

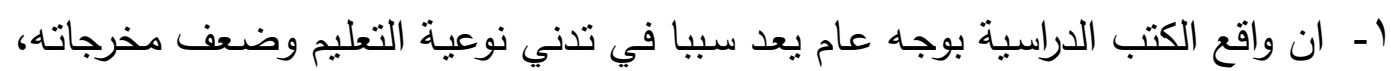

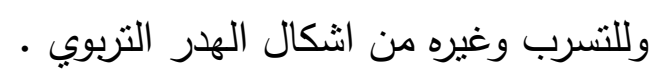

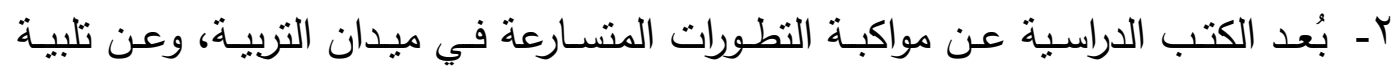

$$
\text { حاجات الطلبة وحاجات المجتمع. }
$$

r- الحاجة المستمرة للتقويم بوصفه وسيلة لتطوير مناهج العلوم بشكل عام ومنهج الاحياء بشكل خاص ـلأهمية هذه الكتب وكونها العمود الفقري الذي تعتمد عليه العملية التربوية وعمليـة اكسـاب الطالب الخبرات والمهارات والمعلومـات التي تخص البيئة والصـحة

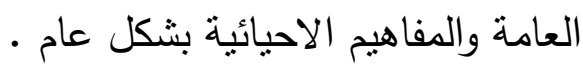

وبذللك يمكن تحديد مشكلة البحث بتقويم محتوى كتاب علم الاحياء للصف الرابع العلمي من وجهة نظر اعضاء الهيئة التدريسية .

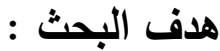

يهدف البحث الحالي الى : تقويم كتاب الاحياء للصف الرابع العلىي من وجهة نظر اعضلاء

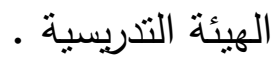

$$
\text { حقود البحث : حتصر البحث الحالي:- }
$$

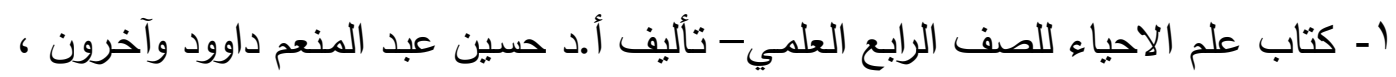

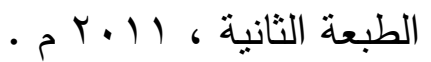

r- اعضاء الهيئة التدريسية لمادة الاحياء في مدارس محافظة بابل المتوسطة والثانوية للعام

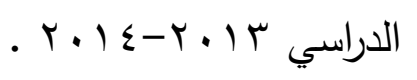




\section{تحديد المصطلحات: \\ - - التقويم}

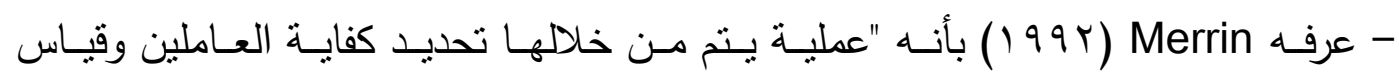

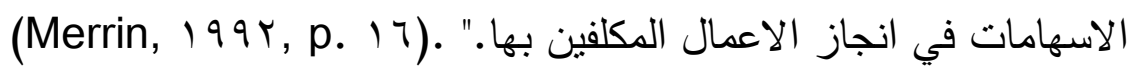

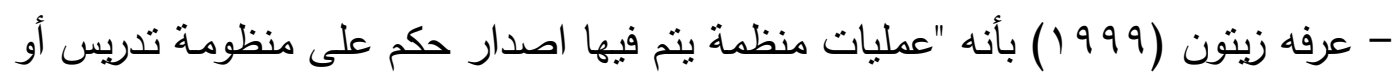

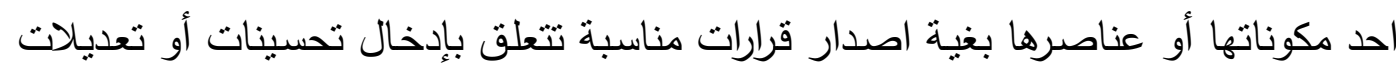

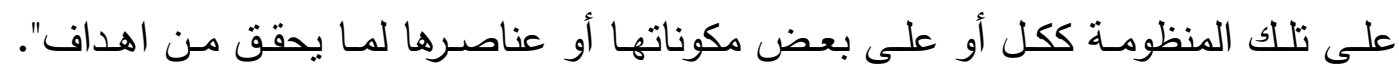

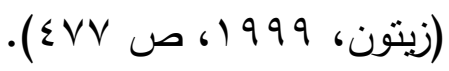

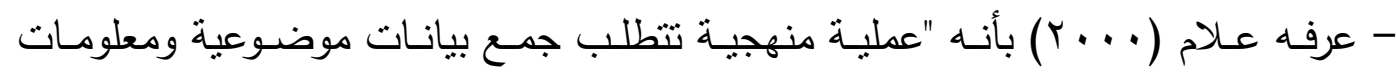

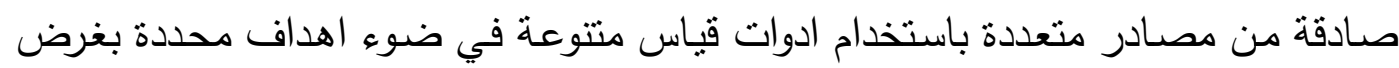

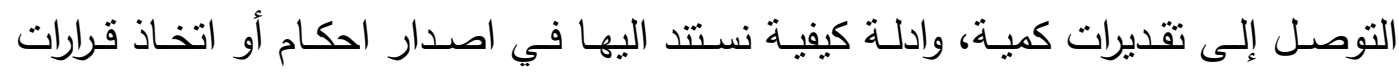

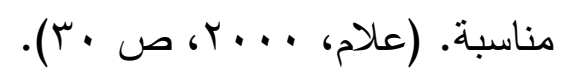

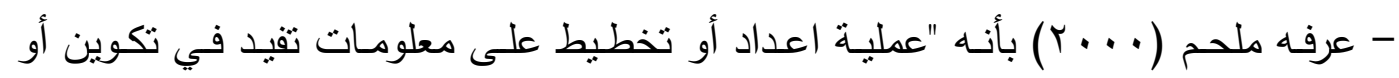

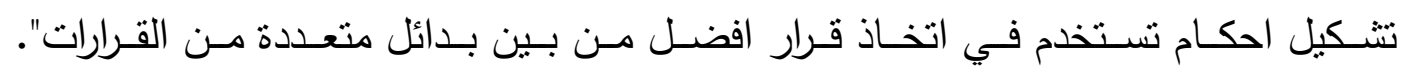

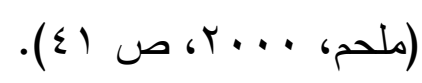

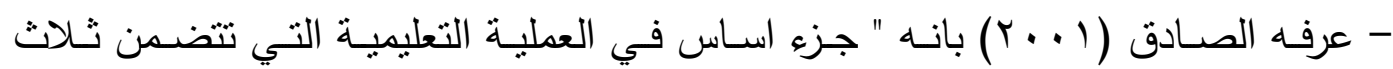

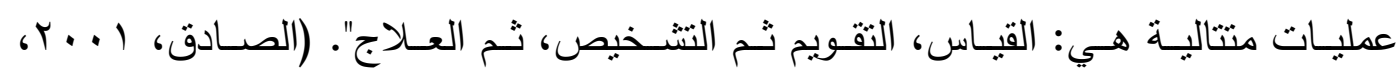

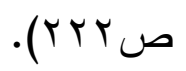

$$
\text { التعريف الاجرائي للتقويم: }
$$

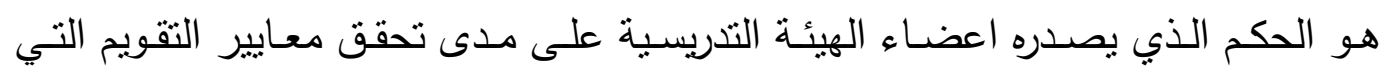

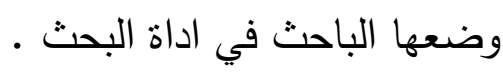

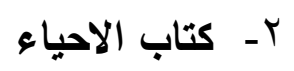

التعريف الاجرائي :- هو احدى عناصر المنهج الدراسي في مرحلة الاعدادية /الفرع العلمي التي تتضمن معلومات علمية عن البيئة والصحة العامة والكائنات الحية والعلاقات الاحيائية والمفاهيم الاحيائية بشكل عام . 
ب-الصف الرابع العلمي : هو عبارة عن المستوى الدراسي الاول من ضمن المستويات الثلاثة

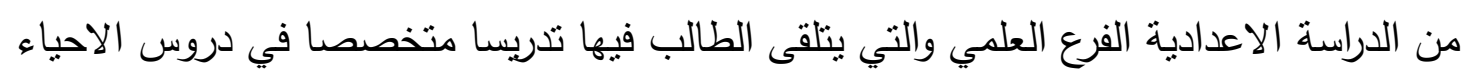
والفيزياء والكيمياء .

\section{الفصل الثاني}

\section{دراسات سابقة}

يتضمن هذا الفصل استعراضاً للاراسات السابقة التي تم التوصل إليها متضمنة أهدافها

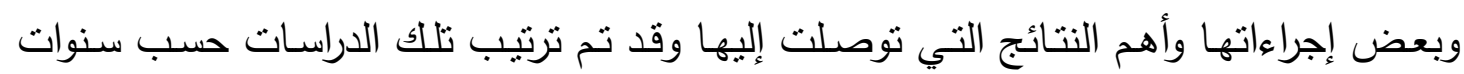
إنجازها على نحو تصاعدي سواء أكانت تلك الدراسات عربية أم أجنبية أولاً: دراسات عربية

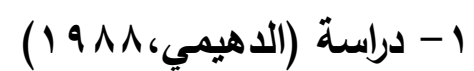

(تقويم كتـاب الأحياء للصف السـادس العلمي مـن وجهـة نظـر المدرسين والمدرسـات

$$
\text { - هالاختصاصيين التربوبين). }
$$

هدفت الدراسـة إلى تقويم كتاب علم الأحياء للصف السـادس العلمي للسـنة الدراسبية

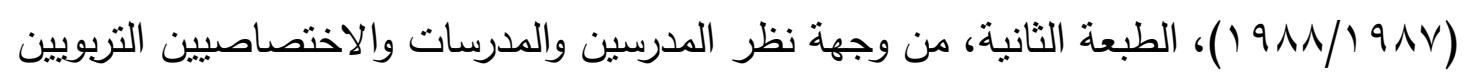

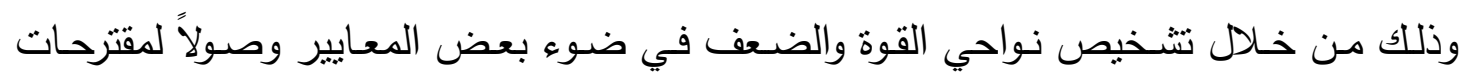

- حدود الدراسة : اقتصرت الدراسة على:

1- مدرسو ومدرسـات كتاب علم الأحياء للصف السـادس العلمي مـن خريجي كليـات التربيـة

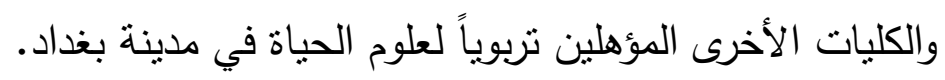
r- الاختصاصيون التربويون لمادة علوم الحياة.

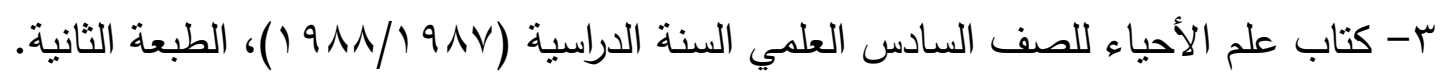

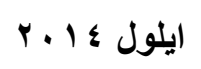


- عينة الدراسة: اشتملت عينة الدراسة على:

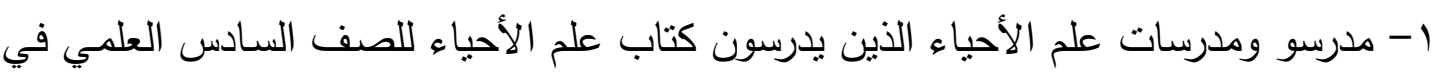

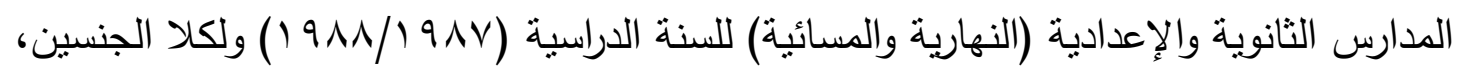

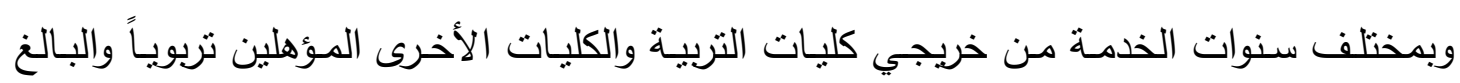

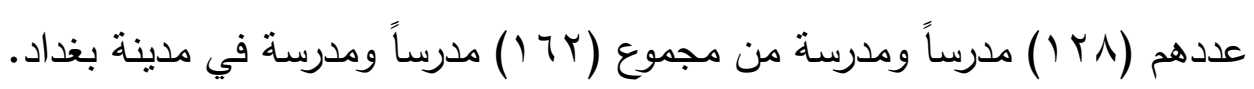

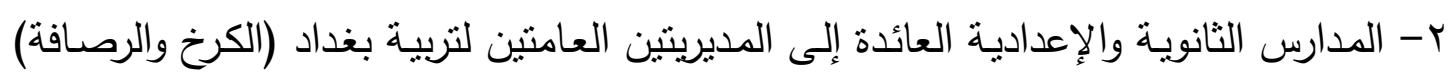

$$
\text { والبالغ عددهم (ب أ ا ) مدرسة. }
$$

r- الاختصاصيون التربويون لمادة علوم الحياة في كلا المديريتين العامتين لتربية بغداد (الكرخ

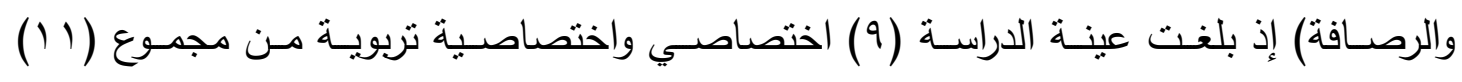
اختصاصي واختصاصية تربوية.

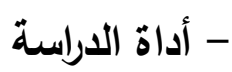

استخدم الباحث استبانة مؤلفة من ستة مجالات احتوت (10) سؤالاً تفرعت إلى (ع (1) )

فقرة، بضدنها سؤال واحد مفتوح.

$$
\text { - الوسائل الإحصائية - }
$$

استخدم الباحث: معامل ارتباط بيرسون والوسط المرجح والوزن المئوي. وسائل إحصائية لبحثه.

$$
\text { - أ أهم النتائج }
$$

1- باعت مادة الكتاب الفروق الفردية بين الطلبة.

ץ- حجم مادة الكتاب يتتاسب مع عدد الساعات المقررة له في الخطة السنوية. r- نساعد مادة الكتاب على إعداد الطلبة للالتحاق بالدراسة الجامعية.

$$
\text { ب- الجوانب السلبية. }
$$

1- إن جانب تتمية الاعتزاز والتقدير بدور العلماءوأثرهم في مجال علوم الحياة ضعيفة في

$$
\text { مادة الكتاب. }
$$

ץ- إن معظم مـادة الكتاب تعتمـد على الناحيـة النظريـة دون الاهتمـام بالجانـب العملـي

$$
\text { التطبيقي. }
$$

r- افتقار الكتاب إلى الأسئلة الموضوعية في نهاية كل فصل. 
ع - إن قسماً من مادة الكتاب جاء دون مستوى الطلبة، وارتباطها بييئتهم كان ضعيفاً.

$$
\text { - أهم التوصيات }
$$

1- وضع دليل للمدرسين يتتاول تدريس الكتاب.

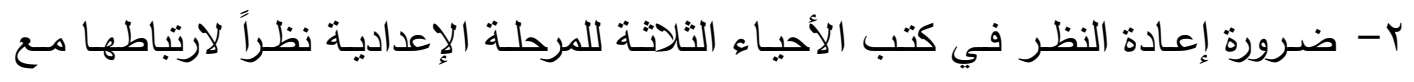

$$
\text { بعضها وتكاملها. }
$$

r- ضرورة عدم التوسع في الموضوعات النظرية على حساب الجانب العملي.

- أهم المقترحات

1- دراسة ممانلة للاراسة الحالية لكتابي علم الأحياء للصفين الرابع العام والخامس العلمي. r- دراسة تقويمية للصور والأشكال التوضيحية في كتب الأحياء للمرحلة الإعدادية.

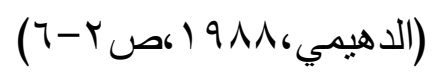

ب - براسة (العكيلي، • 99 (19)

(تقويم كتابي العلوم الموحدة لدول الخليج العربي للصفين الأول والثاني الابتدائي من وجهة نظر المعلمين والمشرفين).

- هذف الاراسة

تقويم كتابي العلوم الموحد لدول الخليج وفقاً للمعايير الآتية

1- مدى تحقيق الكتابين للأهداف التي أعدا من أجلها.

Y- مدى ملائمة موضوعات الكتابين لمستوى التلاميذ.

r- مدى تتاسب موضوعات الكتابين للحصص الدراسية المقررة.

ع - كفاية الأنشطة التعليمية في الكتابين.

0- بنود التقويم ومدى شمولها وكفايتها.

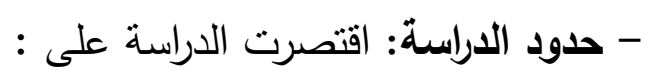

1- المعلمون والمعلمات الذين يقومون بتدريس أحد هذين الكتابين فقط ولسنتين منتاليتين في

$$
\text { المدارس الابندائية في أمانة بغداد. }
$$

ץ- المشرفون التربويون في المديرية العامة لتربية بغداد الكرخ والرصافة.

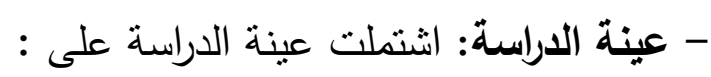




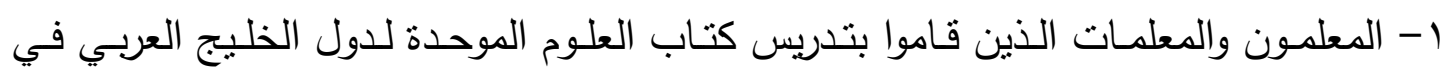

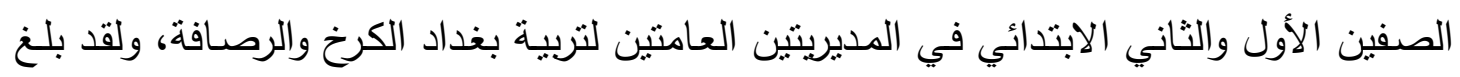
مجموع العينة (. r. r) معلماً ومعلمة. r- الددارس الابتدائية (النهارية والمسائية) العائدة إلى المديريتين العامتين لتربية بغداد (الكرخ والرصافة) والبالغ عددها ( (10 ) مدرسة ابتدائية ولكلا الجنسين. r- المشرفون التربويون ذووا الإثراف العام في وحدتي الإثراف في قاطع الكرخ والرصافة وذللك

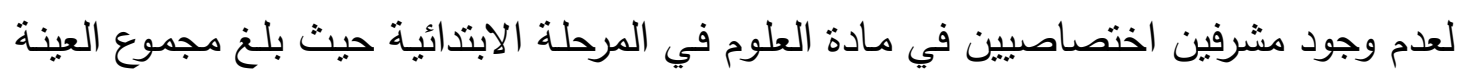

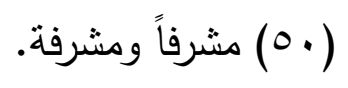

- أداة الدراسة

استخدم الباحث استبانة مؤلفة من ستة مجالات احتوت (0 1) سؤالاً تفرعت إلى (r • () فقرة.

\section{- الوسائل الإحصائية}

استخدم الباحث: النسبة المئوية،، الوسط المرجح،معامل ارتباط بيرسون، الوزن المئوي.

$$
\text { أ - أهم النتائج إيصائية لبحثه. }
$$

1- إن مادة الكتابين قد حققتا الأهداف التي أعدا من أجلها. ץ- إن المادة العلمية التي احتواها الكتابان كانت ملائعة لمستوى التلاميذ ومراعية للفروق الفردية ومرتبطة بييئتهم.

ب- إن الأثطة التعليميـة المصاحبة أظهرت بأنها متتوعـة وشـاملة ومثيرة لتفكير التلاميذ

$$
\text { وتتمي العمل الجماعي لديهم. }
$$

ع - إن بنود التقويم التي احتواها الكتابان كانت مناسبة لأعمار التلاميذ وتتمي لديهم الميول

$$
\text { ب-الجوانب السلبية. }
$$

1- عدم تتاسب حجم الكتاب مع الخطة السنوية المعتمدة. ץ- صعوبة بعض الموضوعات منل " الاحتكالك يعطينا الحرارة، السطح المائل ". 


\section{- أهم التوصيات}

1- تقليص المادة العلمية الموجودة في كتاب علوم الثاني الابتدائي وجعله جزءاً واحداً بدلاً

من جزئين لكي يستطيع المعلم إكمال المادة بحرية دون تسرع فيها.

r- حذف الموضوعات الصعبة في كتاب الصف الثاني مثل موضوعي " الاحتكاك بعطينا

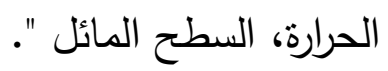

$$
\text { - أهم المقترحات }
$$

1- إجـراء دراسـة تقويميـة لكتابي العلوم الموحدة للصفين الثالث والرابـع مـن وجهـة نظـر المعلمين والمشرفين.

r- تقويم الصور والرسوم التوضيحية في كتابي العلوم الموحد لدول الخليج العربي للصفين

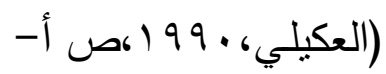
الأول والثناني ابتدائي.

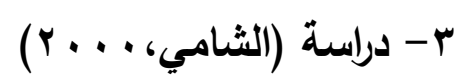

(تقويم مناهج الرياضيات للصفوف الأربعة الأولى في مرحلة التعليم الأساسي بالجمهورية اليمنية)

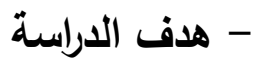

هدفت الدراسة إلى تقويم مناهج الرياضيات للصفوف الأربعة الأولى من التعليم الأساسي بالجمهورية اليمنية. من خلال الإجابة على الأسئلة الآتية:-

1- ما هي معايير تقويم مناهج الرياضيات للصفوف الأربعة الأولى من التعليم الأساسي ؟ r- ما مدى تحقيق هذه المعايير في مناهج الرياضيات المذكورة ؟

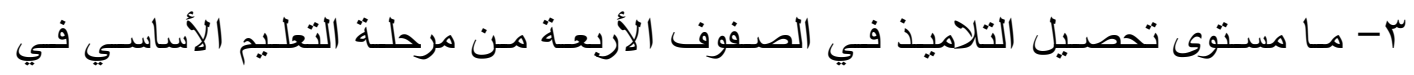

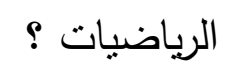
- حدود الدراسة: اقتصرت الدراسة على: 1- مناهج الرياضيات للصفوف الأربعة الأولى من مرحلة التعليم الأساسي باليمن. r- مدرسو الرياضيات للصفوف الأربعة الأولى والإداريون والمشرفون والاختصاصيون. r- بـ مدارس أمانة العاصمة صنعاء. ع- العام الدراسي (99199/1991). 
- عينة الاراسة: اثنتملت عبنة الدراسة على:

$$
\text { 1 - (r ( ) مدرسة أساسية منها (r) مدارس أهلية. }
$$

ץ- (• • • ) تلميذ وتلميذة من الصف الأول إلى الصف الرابع الأساسي أجري عليهم اختبار

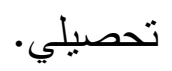

r- (• (V) مدرس ومدرسة لمادة الرياضيات يدرسون في الصفوف الأربعة الأولى من التعليم

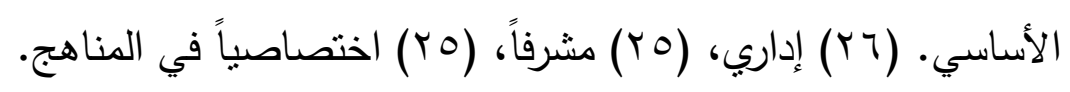

- أداة الاراسة: استخدم الباحث الأدوات الآتية:

1- اختبارات تحصيلية للصفوف الأربعة الأولى من مرحلة التعليم الأساسي كل اختبار صفي

$$
\text { مكون من (Y0) سؤال. }
$$

r- استبانة لمعرفة أراء المدرسين والإداريين والمشرفين التربوبين والاختصاصيين في المناهج

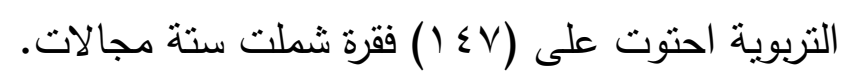

- الوسائل الإحصائية

استخدم الباحث: النسبة المئوية،، الوسط المرجح،معامل ارتباط بيرسون، الوزن المئوي،

تحليل التباين، وسائل إحصائية لبحثه.

$$
\text { - أ أهم النتائج }
$$

1- إن معظم الأهداف واضحة ومحددة وتربط بين المادة العلمية وقضايا البيئة. r- بعض الأهداف واقعية وقابلة للنحقيق.

$$
\text { ب-الجوانب السلبية. }
$$

1- ضعف عام في إجراء العمليات الحسابية الأربع (الجمع، الطرح، الضرب، القسمة).

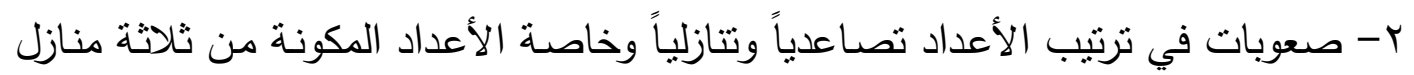

$$
\text { أو أكثر. }
$$

r- صعوبة في كتابة الكسور الاعتيادية والعشرية بالصفين الثالث والرابع أساسي.

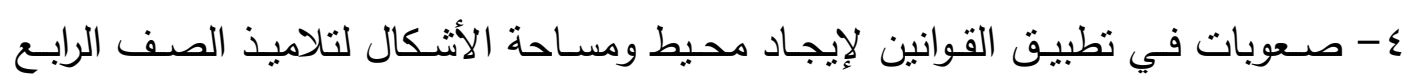
أساسي.

ه- ضعف تأهيل المدرسين بالمستوى المطلوب وقلة الدورات التدريبية. 
1- ضـعف التكامل الرأسـي والأفقي في محتوى المنهج والكتب المدرسية وخاصـة لكتب الصفوف الأولى في مرحلة التعليم الأساسي.

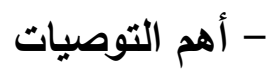

1- إعطاء كل معلم دليل (مرشد) لتوجيه الأنشطة المناسبة وتحديد دور المعلم والمتعلم.

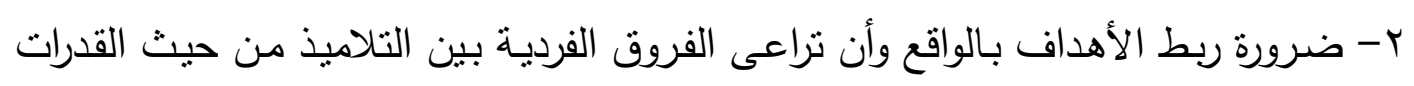
والميول.

r- التتوع في استخدام أساليب التدريس والأنشطة المختلفة بما يتلاءم مع موضوع الدرس.

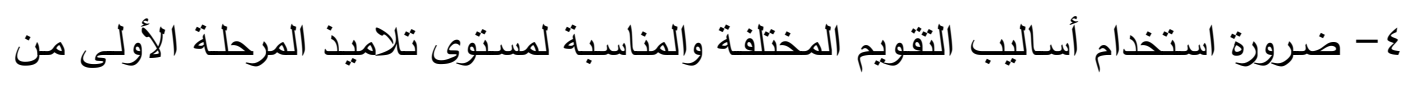
التعليم الأساسي.

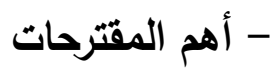

1- إعداد دراسة حول تقويم مناهج الرياضيات للمراحل الأخرى.

r- إعداد دراسة حول طرائق تدريس الرياضيات لمرحلة التعليم الأساسي. r- إعداد دراسة حول أساليب التقويم المستخدمة في التعليم الأساسي.

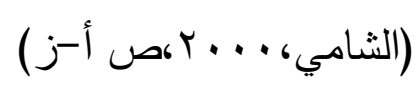

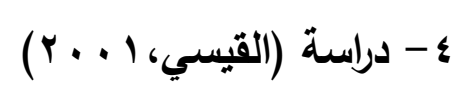

(تقويم كتاب الفيزياء للصف الثناني منوسط من وجهة نظر المدرسين).

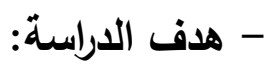

تهدف الدراسة إلى تقويم كتاب الفيزياء للصف الثاني متوسط من وجهة نظر المدرسين.

$$
\text { - حدود الدراسة: اقتصرت الدراسة على: }
$$

1- الددرسون والمدرسات الذين يقومون بتدريس كتاب الفيزياء في الددارس المتوسطة في

$$
\text { ب- الموجعات الآتية كمعايير لتقويم الكتاب. الكعافة في بغداد. }
$$

أ- مدى ملائمة المادة العلمية للكتاب لمستوى الطلبة.

ب-الصور والرسوم التوضيحية من حيث وضوحها، حداثثها، ومناسبتها لمستوى الطلبة. - عينة الاراسة: اشتملت عينة الدراسة على:- 
1- جميع مدرسي ومدرسات الفيزياء في المدارس الثنانوية في مديريات التربية العامة لمدينة

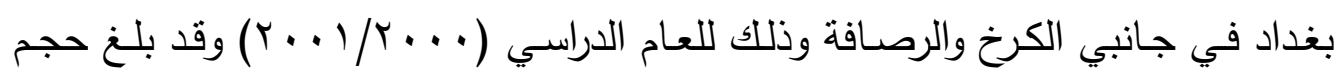
العينة الأساسية (71) مدرس ومدرسة. r- المدارس المتوسطة في قاطعي الكرخ والرصافة في بغداد.

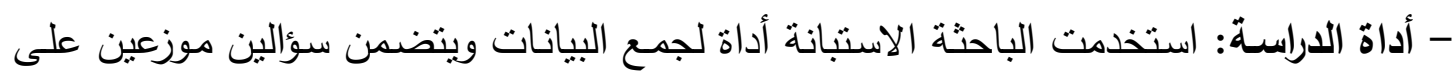
المجالين هما:

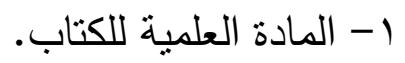
r- ب الصور والرسوم التوضيحية. - الوسائل الإحصائية

استخدمت الباحثة: معامل ارتباط بيرسون، الوسط المرجح، وسائل إحصائية لبحثها.

$$
\begin{aligned}
& \text { - أهم النتائج } \\
& \text { أ- الجوانب الإيجابية. } \\
& \text { أولاً: المادة العلمية للكتاب }
\end{aligned}
$$

1- إن المادة العلمية في كتاب الفيزياء قد راعت مستوى النضج العقلي للطلبة واهتماماتهم

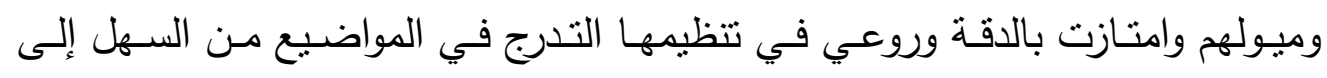

r- امتازت المادة العلمية بحداثتها وترابطها وعدم تكرارها كما راعت الفروق الفردية. ثانياً: الصور والرسوم التوضيحية 1 - كافية ومتتوعة في مضمونها وامتازت بالحداثة وهي ذات علاقة مباشرة بالمادة وارتباطها

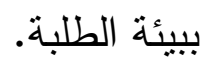
ب-الجوانب السلبية. أولاً: المادة العلمبة للكتاب ا- إن المادة العلمية لا تحوي على عنصر التشويق. r- إن المادة العلمية غير متصلة ببيئة الطلبة العراقية. ثانياً: الصور والرسوم التوضيحية 1- إن الصور والرسوم التوضيحية لا تثري المحتوى بمعلومات كافية. 


\section{- أهم التوصيات}

1- الاهتمام بزيادة الأمثلة والرسوم التي لها علاقة بييئة الطالب العراقية.

ץ- الاهتمام في اختيار الصور والرسوم التوضيحية بحيث تحوي عنصر التشويق، وتثري

المحتوى بمعلومات كافية.

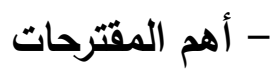

1- إجـراء دراســة تقويميـة للصـور والرسـوم التوضـيحية في كتـاب الفيزيــاء للصف الثنالث المتوسط.

r- إجراء دراسة تقويمية لكتابي الفيزياء في الصف الثناني والثالث المتوسط في ضوء تتميتها للاتجاهات والميول العلمية لدى الطلبة.

(القيسي، (19-I )

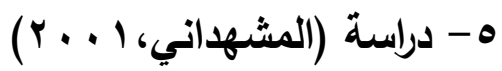

(تقويم منهج التربية الفنية للمرحلة المنوسطة من وجهة نظر الددرسين والمدرسات)

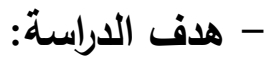

هدفت الدراسة إلى تقويم منهج التربية الفنية للمرحلة المتوسطة من وجهة نظر المدرسين والمدرسات من خلال الإجابة عن السؤالين الآتيين:-

1- ما هي المعايير الواجب توافرها في منهج التربية الفنية في المرحلة المنوسطة؟ r- ما هي المقترحات لنطوير منهج النتربية الفنية للمرحلة المتوسطة. - حدود الاراسة: اقتصرت الدراسة على:

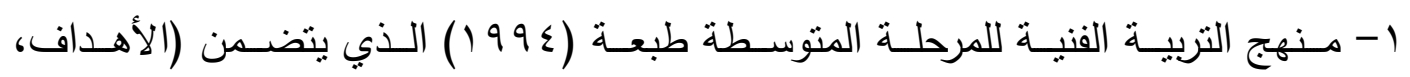

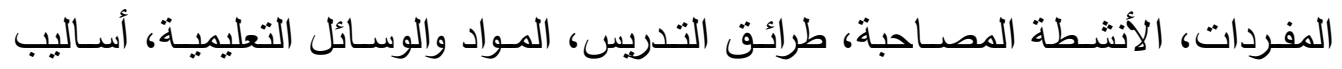

$$
\text { التقويم). }
$$

r- مدرسو ومدرسات مادة التربية الفنية في المدارس المتوسطة النهارية في محافظة بغداد

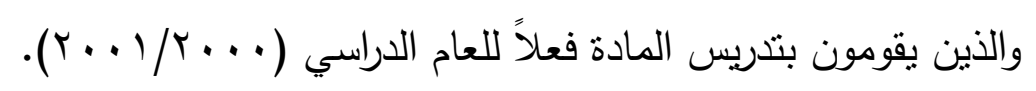

- عينة الدراسة: اشتملت عينة الدراسة على:

1- مدرسو ومدرسات التربية الفنية الذي يعملون في المدارس المنوسطة وقد بلغ حجم العينة

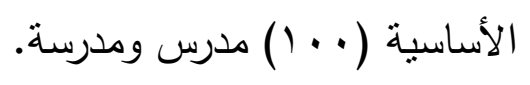


ץ- مجتمع المدارس المتوسطة لمدينة بغداد (الكرخ والرصافة) ولكلا الجنسين والبالغ عددها (. المدا

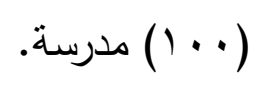

- أداة الدراسة: استخدمت الباحثة استبانة مؤلفة من ستة مجالات شملت (7 م ـ ( ) فقرات

$$
\text { - الوسائل الإحصائية }
$$

استخدمت الباحثة: النسبة المئوية، الوسط المرجح، معامل ارتباط بيرسون، الوزن المئوي،

$$
\begin{aligned}
& \text { وسائل إحصائية لبحثها. } \\
& \text { - أهم النتائج } \\
& \text { أ- الجوانب السلبية }
\end{aligned}
$$

1- إن الأهداف التربوية المعتمدة لمادة التربية الفنبة على الرغم من إيجابياتها فإنها بحاجة

$$
\text { إلى التجديد والإضافة. }
$$

r- عدم التزام بعض المدرسين والمدرسات بتطبيق المفردات حسب ما مقرر لها. r- افتقار المنهج إلى التتويع في أساليب تقويم نتاجات الطلبة.

$$
\text { ع - الاقتصار في التنريس على عدد محدد من المفردات }
$$

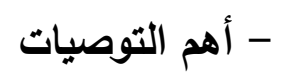

1- إعادة النظر بالأهداف العامة لمنهج التربية الفنية في المدارس المنوسطة بشكل يضمن

$$
\text { الوضوح والدقة والثمول والحداثة. }
$$

ץ- ضرورة الاهتمام بدروس التربية الفنية وعدم استخلالها لتدريس مواد أخرى.

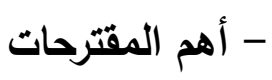

1- إجراء دراسـة تقويمية للمنهج الجامعي في كلية الفنون الجميلة/ قسم التربية الفنية الذي ينولى إعداد المدرسين لتدريس هذه المادة.

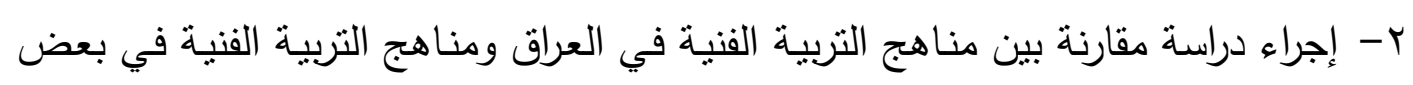

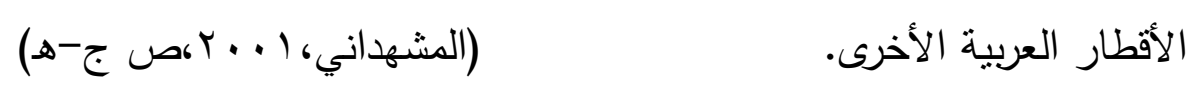

الفصل الثالث 
1-مجتمـع البحث :- تكون مجتمع البحث من مدرسي ومدرسات مادة علم الاحياء للصف الرابع

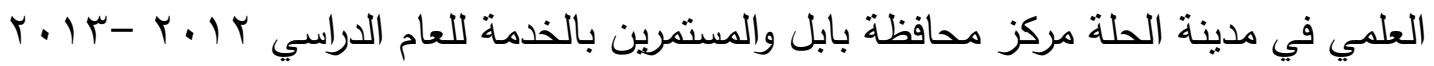
r- عينـة البحث :- تكونت عينـة البحث من عينـة عشوائية من اعضـاء هيئة التدريس مكونة من

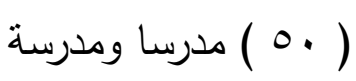

ب-اداة البحث :- واعتمد الباحث الاداة التي اعدها بنفسه وبالاعتماد على دراسات سابقة وعرضت الاداة على مجموعه من الخبراء في مجال التربية وعلم النفس وكان الاتفاق على الفقرات التي ذكرت

في الاداة وكان عدد فقرات هو ( ع7 ) فقرة كما موضح في ملحق رقم ( (1) ع-الصدق :- لغرض التحقق من صـلاحية اداة البحث اعتمد الباحث على الصدق الظاهري في ذللك اذا قام بعرض الاستبيان على عينة محكمة من ذوي الاختصاص في مجال علم النفس وطرائق تدريس العلوم وطرائق تدريس العلوم الاجتماعية ملحق رقم ( r ) • وقد اخذ الباحث ( • م \% ) فاكثر معيارا لقبول الفقرات الاستبيان ( عودة . 1991 ص rVo ) وقد حصلت جميعها على هذه النسبة واكثر 0- الثبات :- اعتمد الباحث اسلوب الاهادة في التحقق من ثبات الاستبيان على عينة استطلاعية من مدرس ومدرسات مادة الاحياء للصف الرابع العلمي بلغ عددها ( • ( ) من غير العينة الاساسية

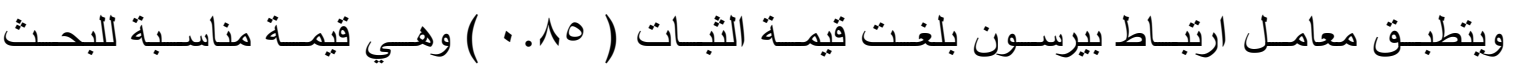

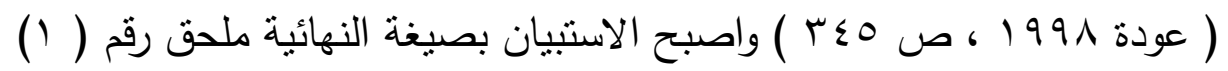
צ-تطبيق البحث :- قام الباحث بتطبيق الاستبيان على افراد العينة الاساسية من مدرسي ومدرسات مادة الاحباء للصف الرابع العلمي بتاريخ 1-ع - ( ـ ب وقد راعي الباحث وضوح فقرات الاستبيان وذلك بتوضيح الفقرات غير الواضحة للعينة المستهدفة . V-تصحيح اداة البحث :- لغرض تحليل البيانات احصائيا حولت استجابة افراد العينة على فقرات الاستبيان الى ارقام يمكن معالجنها احصائيا ، ووضع الباحث لكل فقرة من فقرات الاستبيان ثلاثة بدائل متدرجة بمستوياتها لكل فقرة من فقرات الاستبيان (كبيرة ، متوسطة ، قليلة ) حيث بلغ عدد

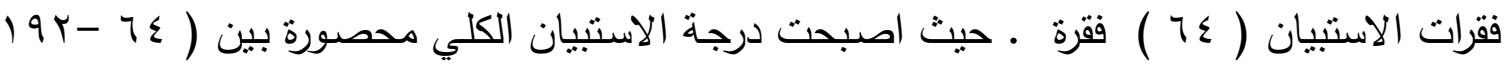
) درجة 1- الوسائل الاحصائية :- استخدم الباحث الوسائل الاحصائية التالية 1- معامل الازتباط بيرسون :-

$\sum x y-\left(\sum x\right)\left(\sum y\right)$ 


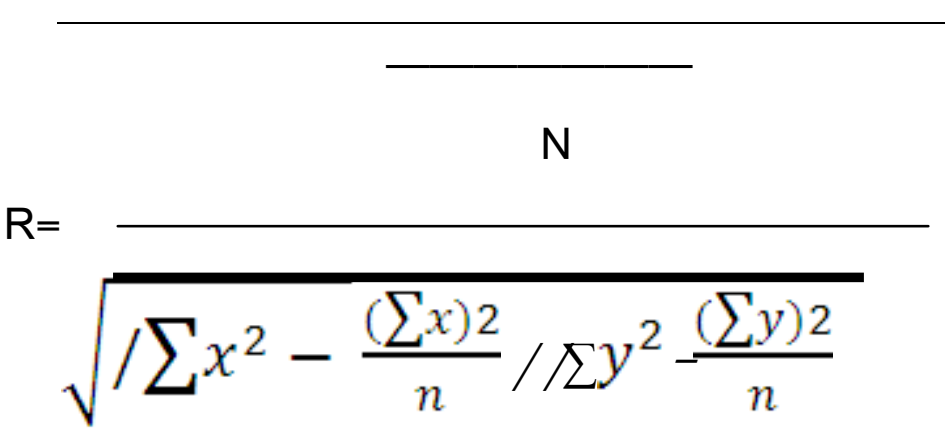

$$
\begin{aligned}
& \text { حيث ان :- } \\
& \text { R } \\
& \text { N }
\end{aligned}
$$

Exy

(

الاستبيان في الفترة الثانية .

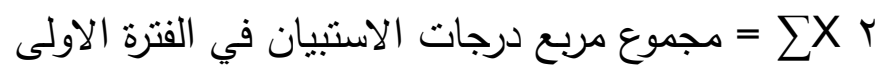

=

Eyr

= مربع مجموع درجات الاستبيان في الفترة الثانية

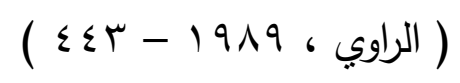

r- الوسط المرجح واستخدم لإستخراج حدة الفقرة . $W|X|+W r X Y+W r X r+W \leqslant X \leqslant+W 0 X 0$

$$
X=
$$

$W_{1}+W r+W r+W \varepsilon+W_{0}$

$$
\text { حيث x = الوسط المرجح }
$$

قيمة الفترة بالدرجة = X

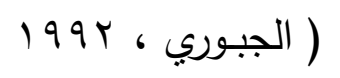

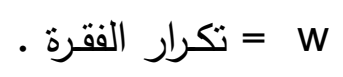

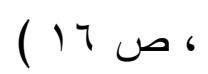

r- الوزن المئوي للفقرة = الوسط المرجح ( حدة الفقرة ) × . 1 
العدد السابع عثر

مجلة كلية التربية/جامعة واسط

الدرجة القصوى

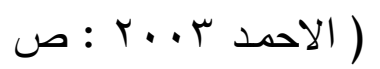

الدرجة القصوى = اعلى درجة في الدقياس الثلاثي

( 171 


\section{الفصل الرابع}

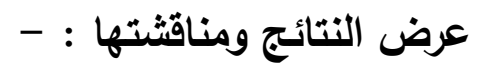

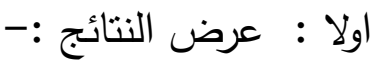

فيما يتعلق بهذف البحث وهو تقويم كتاب الاحياء للصف الرابع العلمي من وجهاه نظر أعضاء

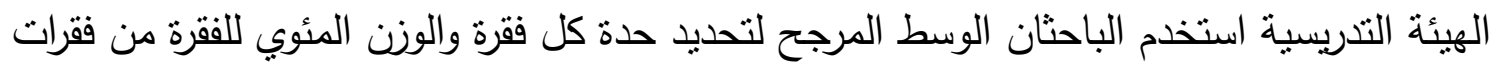

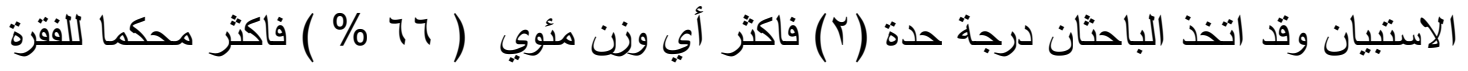

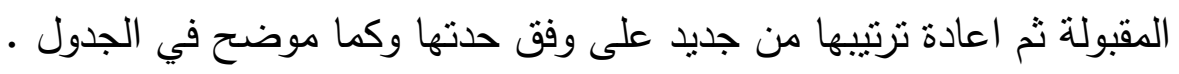

\section{جدول (1)}

حدة الفقرات والوزن المئوي والترتيب الجديد لفقرات الاستبيان من وجهة نظر المدرسين والمدرسات

\begin{tabular}{|c|c|c|c|c|}
\hline الترتيب الأصلي & المزن المئوي & حدة الفقرة & الفقرات & ت \\
\hline ir & $\% 9 \wedge, 7$ & $r, 97$ & التأمل في عظمة الخالق عز وجل في أبداع خلقة ( أهداف الكتاب ) & 1 \\
\hline r & $\% 9 V$ & $r, q r$ & تتضمن أهمية علم الأحياء ( مقدمة الكتاب ) & r \\
\hline$r$ & 97,7 & $r, q$ & تتضمن فكرة عامة عن محتوى الكتاب ( مقدمة الكتاب ) & $r$ \\
\hline $7 \cdot, V$ & $\% 97$ & $r, \wedge \wedge$ & تعبر عن المحتوى ( أهداف الكتاب ) وضوح عناوين الموضوعات ( & $\varepsilon$ \\
\hline$\wedge$ & $\% 9 \varepsilon$ & r,AY & تتسم بالدقة العلمية والوضوح ( أهداف الكتاب ) & 0 \\
\hline 09 & $\% 9 r$ & $Y, V T$ & وضوح الحروف ( حجم الحروف ) ( أخراج الكتاب) & 7 \\
\hline $7, \leqslant 1$ & $\% 7_{6} \cdot 9$ & $V T_{6} r$ & ملائمة للمرحلة العمرية للطالب (أهداف الكتاب ) & V \\
\hline$r 96 r .619$ & 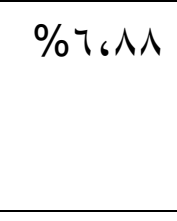 & $776 r$ & 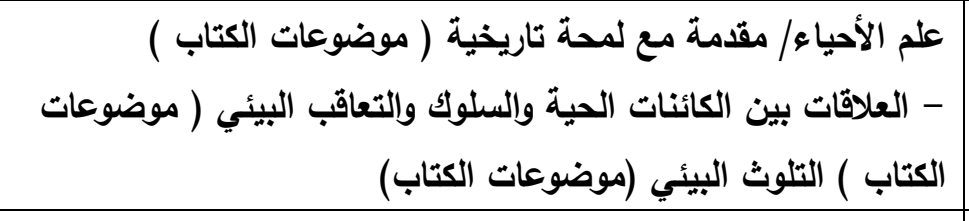 & $\wedge$ \\
\hline $1 \mu_{6} r$. & $\% \wedge \wedge$ & $T \leqslant 6 r$ & 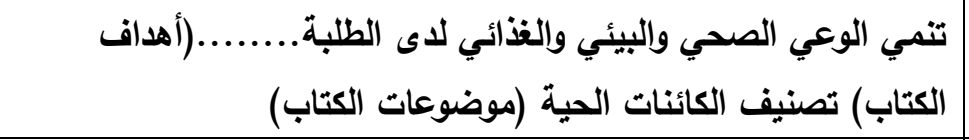 & 9 \\
\hline$\varepsilon$. & \%r،AV & $T r_{6}$ & تدرجها من الأسهل إلى الأصعب ومن البسيط إلى المركب (أسئلة نهاية & 1. \\
\hline
\end{tabular}




\begin{tabular}{|c|c|c|c|c|}
\hline & & & الفصل ) & \\
\hline 1 & $\% \wedge \vee$ & TYG & موضحة للأهداف التعليمية للكتاب (أهداف الكتاب) & 11 \\
\hline$\mu_{q} \leqslant 0$ & $7 . \wedge 7$ & $7, Y$ & متلى فهم الموضوع من حيث الصياغة (أسئلة نهاية الفصل ) مساعدة الطالب (النظادة العلمية ) (النشاط) & ir \\
\hline Y.6rT,or.TI & $\% \wedge 7$ & $O \Lambda_{6} Y$ & 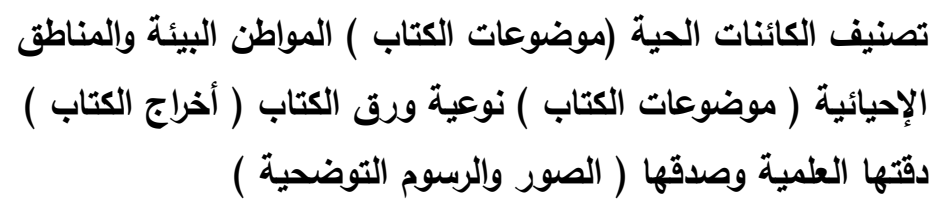 & ir \\
\hline $1 \leqslant 6 \leqslant 967 \leqslant$ & $\%$ \% & 07,5 & ريط المعرفة العلمية بحياة الطالب اليومية (..............(أهداف) & $1 \varepsilon$ \\
\hline r r.ro, & $7 . \wedge \varepsilon$ & $0 \leqslant 6 r$ & مع المواطن البيئة والمناطق الإحيائية (موضوعات الكتاب ) تلاؤم الحيوان & 10 \\
\hline$\varepsilon$ & \%ऍ،八 & $0, Y$ & تعين المدرس على البدء بالدرس (مقدمة الكتاب ) & 17 \\
\hline $0,1 \cdot 6 r \Lambda_{6} 74$ & $\% \wedge r$ & $\sum 7, r$ & 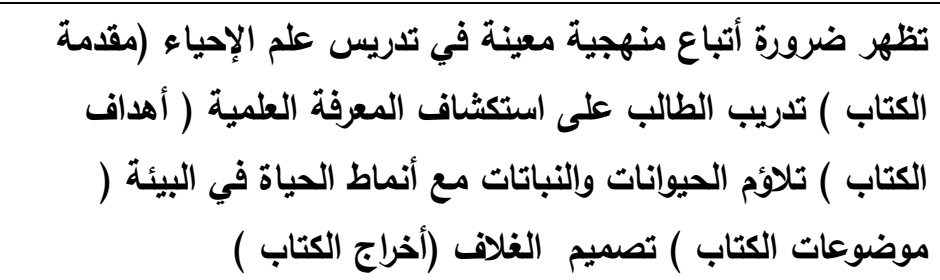 & iv \\
\hline rr & r،八I & r. $\leqslant \varepsilon$ & السلسلة الغذائية ودورة العناصر في الطبيعة (موضوعات الكتاب ) & 11 \\
\hline 9 & \%七،八. & $\sum Y_{6} r$ & تنمي مهارات التفكير العلمي (أهداف الكتاب ) & 19 \\
\hline 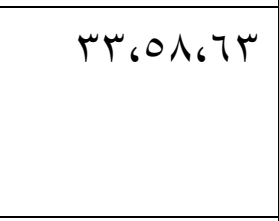 & $\% \wedge$. & $\varepsilon_{6} Y$ & (أخراج الكتاب ) مميزة بين مستويات الطلبة (أسئلة نهاية الفصل ) يخلو من الأخطاء & $r$. \\
\hline $1 \leq 60 \%$ & $\% \vee q$ & HA, & (أهداف الكتاب ) جودة الطالب لدراسة موضوعات كتاب الإحياء للصف الخامس العلمي & $r_{1}$ \\
\hline 0. & \%чเマА & ru, r & كفاية الصور والرسوم التوضيحية & rr \\
\hline TV & $\% \vee \wedge$ & $r \varepsilon_{6} r$ & تلاؤم النبات مع البيئة (موضوعات الكتاب ) & $r r$ \\
\hline$\leqslant 7$ & $\%$ \% $\vee V$ & $r^{r} r^{\prime}$ & يستطيع الطالب القيام به (النشاط ) & $r \varepsilon$ \\
\hline $0 \leqslant$ & $\% \vee v$ & 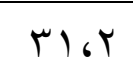 & مساعدتها في فهم الموضوع ( الصور والرسوم التوضيحية ) & ro \\
\hline 11 & 7687 & $r_{6}$ & الكتاب ) مع فلسفة تدريس العلوم وأهداف المجتمع وحاجاته (أهداف & rq \\
\hline
\end{tabular}


العدد السابع عشر

مجلة كلية التربية/جامعة واسط

\begin{tabular}{|c|c|c|c|c|}
\hline $1 \wedge$ & $\% \vee 7$ & rA, $\Lambda^{\prime}$ & غرس الاتجاهات العلمية عند الطلبة (أهداف الكتاب ) & rV \\
\hline$\varepsilon r$ & $7, V Y$ & $1 \Lambda_{6} r$ & شموله لكل الموضوعات (النشاط ) & $r \wedge$ \\
\hline q & $\% \vee r$ & $176 r$ & تراعي الجانب المعرفي للطبة (أسئلة نهاية الفصل ) & rq \\
\hline rtot & rov & $1 \leqslant 6 r$ & مثيرة لرغبة باستعمال مفردات يفهمها الطلبة كافة (أسئلة نهاية الفصل ) & $r$. \\
\hline 17.01 & $\% 79$ & $\cdot \Lambda_{6} Y$ & مواكبة للتطورات العلمية وما يحدث في العالم ( أهداف الكتاب) & r \\
\hline $07.0 \mathrm{~V}$ & 7.71 & .76 & أثثارة التفكير (صور ورسومات ) تلاؤم أعمار الطلبة (صور ورسومات) & rr \\
\hline iv & $\% ч \wedge$ & $\cdot \varepsilon_{6} r$ & تراعي حاجة المجتمع العراقي في ظل الظروف الراهنة ( أهداف الكتاب) & r \\
\hline$\leqslant 1$ & \%тV & $r, \cdot r$ & ارتباطها بالموضوعات والخبرات الواقعية للطلبة & $\mu \varepsilon$ \\
\hline $00 ، \varepsilon \varepsilon$ & \% & 169 & في تثجع الطلبة على التفكير الناقد والإبداعي (النشاط) مدى مساعدتها & ه p \\
\hline ro & $\%$ \% & $16 \wedge 1$ & تمكن الطلبة من إبداء آرائهم & q \\
\hline$\varepsilon r_{6} T_{\Lambda}$ & $\% \pi r$ & $16 \wedge 7$ & تراعي الجانب المهاري (أسئلة نهاية الفصل ) & $r v$ \\
\hline$\sum V_{6} r V$ & $\% 0 \Lambda_{6} 7$ & $16 \times 7$ & تراعي الجانب الوجداني (أسئلة نهاية الفصل ) & $\mu$ \\
\hline$r t$ & $\% \circ r$ & 167 & الأنسجة النباتية (موضوعات الكتاب) & rq \\
\hline
\end{tabular}

ثانياً : مناقنشة النتائج :- (1)

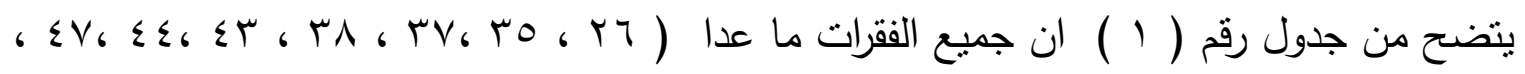
هه ) قد حصلت على اوزان مئوية اعلى من وزن المحك الذي افترضه الباحث والبالغ ( דج \% ) فما فوق وهذا يدل على ان الكتاب قد حصل على نسب مقبولة من معظم المدرسين وفي جميع

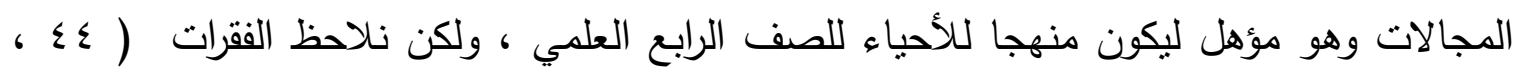
هـ ) والتي حصلت على وزن مئوي (r7 \% ) حيث ان النتائج تدل على ان الكتاب لا يشجع على التفكير الناقد والابداعي وان الرسومات والصور لا تستطيع اثارة الطلبة وهذا من وجهه نظر

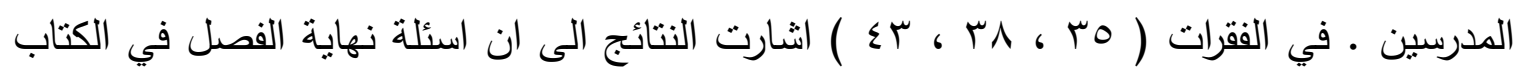
والنشاط لا تمكن الطالب من ابداء رايه ـ ولا تراعي الجانب المهاري • وان الاثشطة المذكورة لا

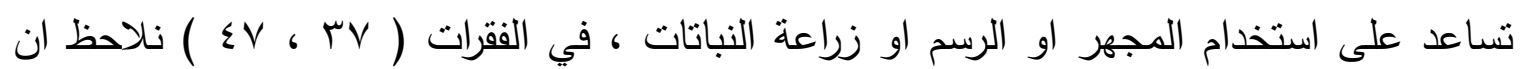
النتائج دلت على اسئلة نهاية الفصل لاتراعي الجانب الوجداني وكذلك لا نساعد النشاطات المذكورة 
على القيام بمشاريع جماعية لدراسة البيئة ، كذلك اشارت هذه الدراسة الى ان موضوع الانسجة

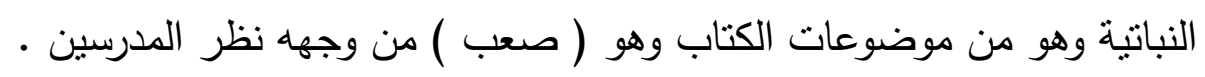
المصادر العربية

1- الاحمد ، ردينة عثمان ، وحذام عثمان • طرائق التدريس ، منهج ، اسلوب ، وسيلة ،

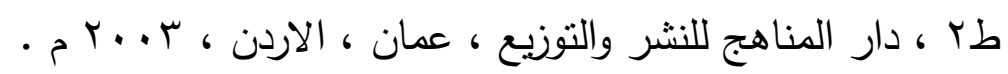
ץ- بحري، منى يونس وعايف حبيب، (910 (). المنهج والكتاب المدرسي، وزارة التعليم العالي والبحث العلمي، جامعة بغداد. ז- البسام، عبد العزيز ابراهيم واخرون، (71911). مشروع تقويم النظام التربوي، وزارة النربية، الكويت. ع- الجبوري ، شلد حبيب عبد الله ـ r 199 ـ الاحصاء التطبيقي ـ دار الحكمة للطباعة والنشر .بغداد 0- الدايني، جبار رشك، (919v1). دراسة تقويمية لاستخدام الاهداف الجارية في تدريس

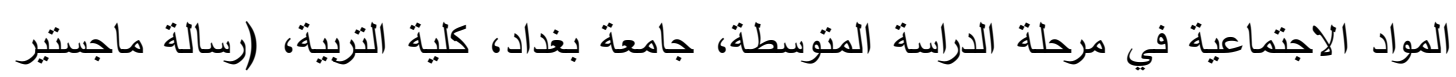
غير منشورة). 7- دمعة، مجيد ابراهيم ومحمد منير مرسي، (ب19 1). "الكتاب الددرسي ومدى ملاءمته لعمليتي التعلم والتعليم في المرحلة الابتدائية"، مجلة وحدة البحوث التربوية ، المنظمة العربية للافقة والعلوم، تونس، صع ؟-TVا.

- - الدهيمي، حميد محمد حمزة، تقويم كتاب علم الأحياء للصف السادس العلمي من وجهة نظر المدرسين والمدرسات والاختصاصيين التربويين، رسالة ماجستير (غير منشورة)، كلية التربية، جامعة بغداد، 911 1.

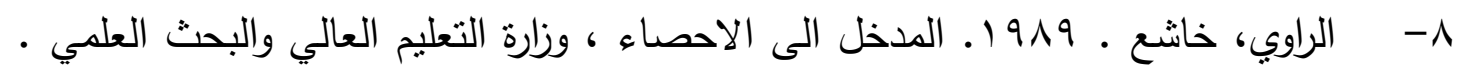

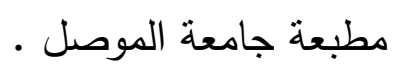

9- رضوان، ابو الفتوح واخرون، (9NVV). المواد الاجتماعية في التعليم العام اهدافها، مناهجها، طرق تدريسها، طس، دار المعارف، القاهرة، مصر 
• 1- زيتون، عايش وعبد اله منيزل (999 (1). "العوامل المؤثرة في تقييم الطلبة لاداء عضو الهيئة التدريسية في الجامعة"، مجلة دراسات العلوم الانسانية، المجلد (؟)، العدد (0)،ص هـ 07 ؛ 11- السامرائي هاشم جاسم واخرون، (990). المناهج أسسها، نطويرها، نظرياتها، دار

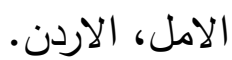

r ا- الثامي، صالح محمد أحمد، تقويم مناهج الرياضيات للصفوف الأربعة الأولى، في

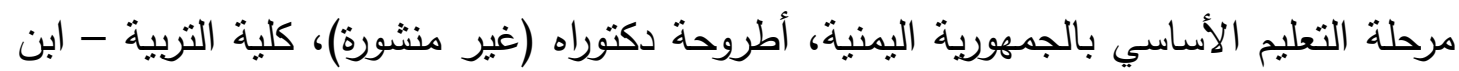

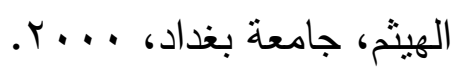

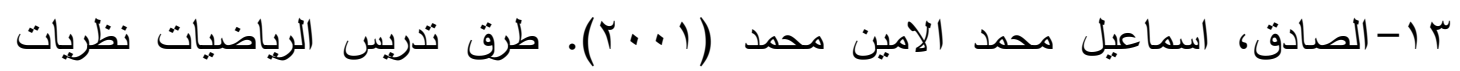
وتطبيقات، طا، دار الفكر العربي، القاهرة. ع ا- العكيلي، أحمد عبد الزهرة سعد، تقويم كتابي العلوم الموحد لدول الخليج العربي للصفين الأول والثاني الابتدائي من وجهة نظر المدرسين والمشرفين، رسالة ماجستير (غير منشورة)، كلية التربية الأولى، جامعة بغداد، . 199. 10- علام، صلاح الدين محمود (........ القياس والتقويم التربوي والنفسي، اساسياته وتطبيقاته وتوجيهاته المعاصرة، طا، دار الفكر العربي، القاهرة. 1 ا- عودة ، احمد سليمان 1991 ـ القياس والثقويم في العملية التدريسية ، الاصدار الثاني ، دار الامل للنشر والنوزيع ، الاردن IV - القيسي، ميسون شاكر عبد الله، تقويم كتاب الفيزياء للصف الثاني متوسط من وجهة نظر المدرسين، أطروحة دكتوراه (منشورة)، مجلة كلية التربية للبنات، جامعة بغداد، المجلد

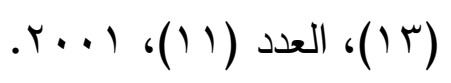

11- اللقاني، احمد حسين، (1990). تطوير مناهج التعليم، طا، عالم الكتب، القاهرة. 9 19- محمد، عبد علي (ب99 (1). الدنهج الدراسي، طا، دار الثقافة، البحرين. • ץ- محد، مجيد مهدي، (1991). المناهج وتطبيقاتها التربوية، وزارة التعليم العالي والبحث العلمي، جامعة الموصل، العراق. 
اب- محد، داود ماهر ومجيد مهدي (1991). اساسيات في طرائق التدريس العامة، دار

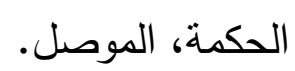

Y Y- المشهداني، مدين محمد، تقويم منهج التربية الفنية للمرحلة المتوسطة من وجهة نظر المدرسين والمدرسات، رسالة ماجستير (غير منشورة)، كلية التربية- ابن الهيثم، جامعة بغداد، $. r+.1$

r ب- ملحم، سامي محمد، (......). القياس والتقويم في التربية وعلم النفس، طا، دار المسيرة للنشر والتوزيع والطباعة، الاردن.

؟ ؟- الهانشي، عابد توفيق، (999 ()). "المنطلقات التطويرية لمناهج الدراسات الاسلامية"،

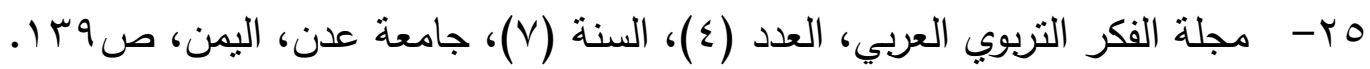

\section{المصادر الانكليزية}

Merrin, C.A Xin Ed (199r) Encrclopedia Educational Research, 7th, Ed. New York: Macmillan publishing company 
ملحق (1)

$$
\text { جامعة القادسية }
$$

م/ استبانة تقويم كتاب الأحياء للصف الرابع العلمي

من وجهة نظر المدرسين والمدرسات

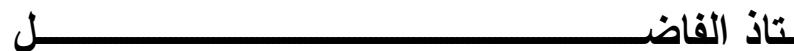

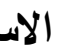

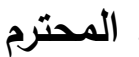

تحية طيبة........

يروم الباحثان إجراء دراسـة تهدف إلى (( تقويم كتاب علم الأحياء للصف الرابع العلمي من

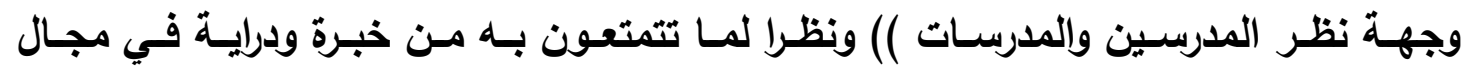

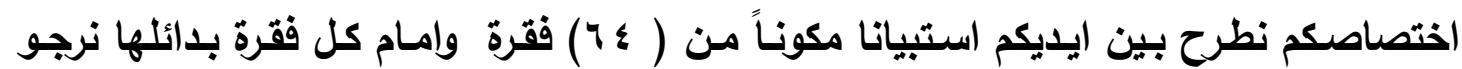
التأثير بعلامة ( صحم) على البديل الذي تراه مناسبا للفقرة المذكورة .... شاكرين تعاونكم خدمة للمسيرة العلمية

مع خالص الاحترام والامتنان 
الباحثان

\begin{tabular}{|c|c|c|c|c|}
\hline بليلة & متوسطة & 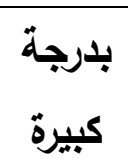 & الفقرة & 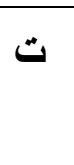 \\
\hline & & & كانت مقدمة الكتاب موضحة للأهداف التعليمية & 1 \\
\hline & & & كانت مقدمة الكتاب متضمنة أهمية علم الأ حياء & r \\
\hline & & & كانت مقدمة الكتاب متضمنة فكرة عامة عن محتوى الكتاب & $r$ \\
\hline & & & كانت مقدمة الكتاب معينة للمدرس على البدء بتدريس الكتاب & $\varepsilon$ \\
\hline & & & كانت مقدمة الكتاب تظهر ضرورة أتباع منهجية معينة في تدريس & $\bullet$ \\
\hline & & & كانت أهداف الكتاب ملائمة للمرحلة العمرية للطالب & 9 \\
\hline & & & كانت أهداف الكتاب ت تعبر عن المحتوى & $\checkmark$ \\
\hline & & & كانت أهداف الكتاب تتسم بالدقة العلمية والوضوح & $\Lambda$ \\
\hline & & & كاتت أهداف الكتاب تنمي مهارات التفكير العلمي & 9 \\
\hline & & & كانت أهداف الكتاب تدريب الطالب على استكثاف المعرفة العلمية & 1. \\
\hline & & & كانت أهداف الكتاب غرس الاتجاهات العلمية لاى الطلبة & 11 \\
\hline & & & خلقه أهداف الكتاب التأمسل في عظمـة الخـالق عزوجل في ابـاع & ir \\
\hline & & & كانت أهداف الكتاب تنمي الوعي الصحي والبيئي والغذائي للاى & ir \\
\hline & & & كانت أهداف الكتاب تهيئة الطالب لدراسـة موضوعات كتاب الأحياء & $1 \leqslant$ \\
\hline & & & كانت أهداف الكتاب ربط المعرفة العلمية بحياة الطالب اليومية & 10 \\
\hline & & & كاتت أهداف الكتاب مواكبة للتطورات العلمية وما يحدث في العالم & 17 \\
\hline & & & كانت أهداف الكتاب تراعي حاجة المجتمع العراقي في ظل الظروف & iv \\
\hline & & & كانت أهداف الكتاب تتفق مع فلسفة تدريس العلوم واهداف المجتمع & 11 \\
\hline
\end{tabular}




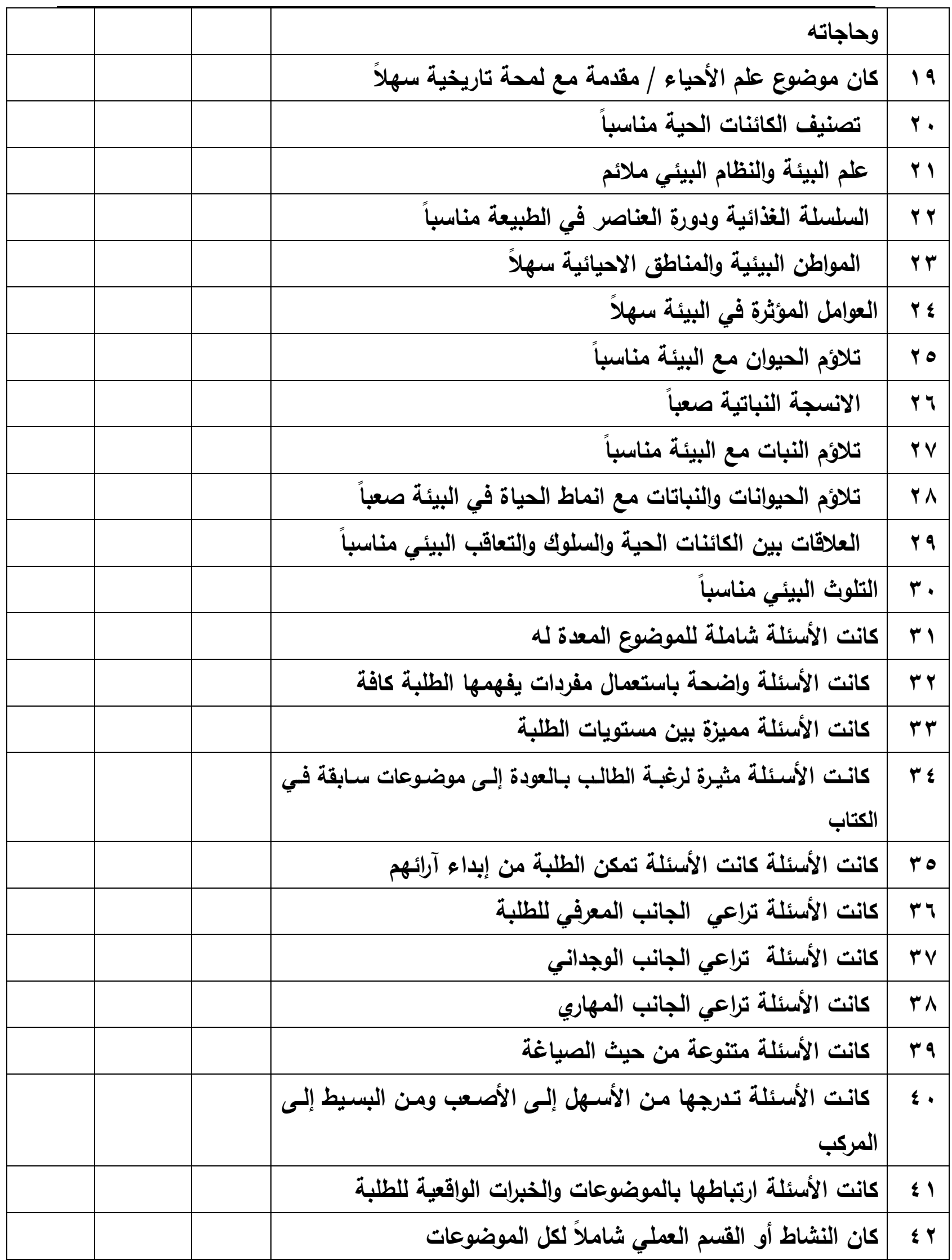




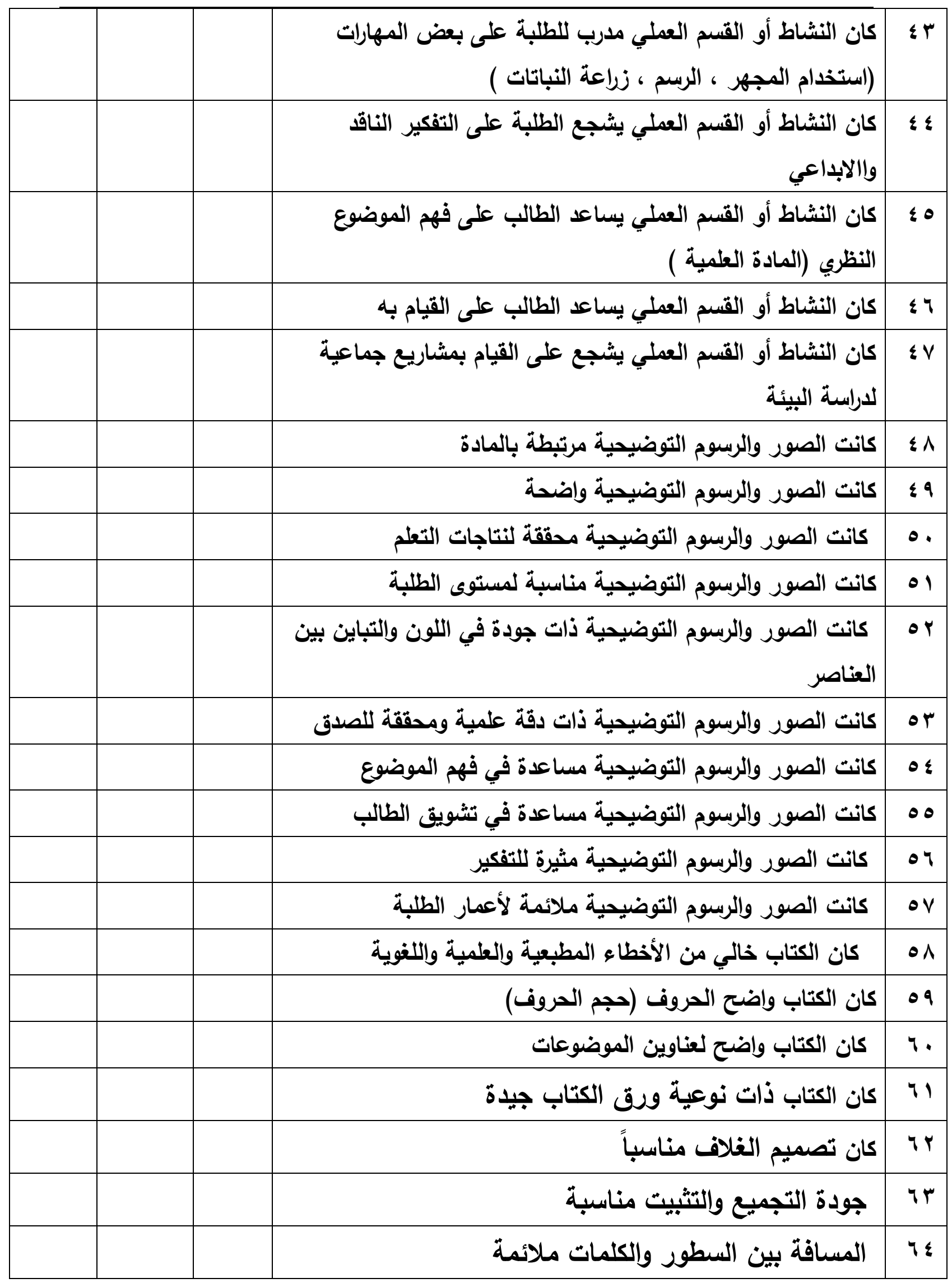


ملحق (r)

اسماء الاساتذة والخبراء الأين طرحت عليهم اداة البحث

\begin{tabular}{|c|c|c|c|}
\hline الاختصاص & الارجة العلمية & اسماء المحكمين & ت \\
\hline طرائق تدريس التاريخ & 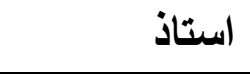 & د. حسين هاشم هندول & 1 \\
\hline علم النفس & استاذ & د. عبد العزيز حيدر & $r$ \\
\hline طرائق تدريس القيزياء & استاذ مساعد & د. هادي كطفان الشون & $\mu$ \\
\hline طرائق تدريس التاريخ & استاذ مساعد & د. حسين جدوع مظلوم & $\varepsilon$ \\
\hline علم النفس & استاذ مساعد & د. علي صكر & 0 \\
\hline طرائق تدريس علوم حياة & مدرس & د. مازن ثامر شنيف & 7 \\
\hline طرائق تدريس علوم حياة & مدرس & د.علاء احمد عبد الواحد & $v$ \\
\hline طرائق تدريس علوم حياة & 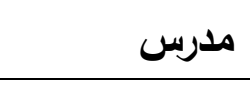 & د. احسان حميد عبد & $\wedge$ \\
\hline طرائق تدريس علوم حياة & مدرس & د. علي رحيم محمد & 9 \\
\hline طرائق تدريس فيزياء & مدرس & د. محسن طاهر & 1. \\
\hline
\end{tabular}

